\title{
Plasma digoxin concentrations and digoxin toxicity in hospital patients
}

\author{
D. C. Evered ${ }^{1,2}$ and C. Chapman \\ From the Department of Nuclear Medicine, The General Infirmary, Leeds
}

Studies were made on 108 subjects on routine oral maintenance digoxin therapy. Twenty-two were found to have evidence of digoxin toxicity. The range of plasma digoxin concentrations in these subjects is recorded $(I \cdot 38 S D \pm 0.77 \mathrm{ng} / \mathrm{ml})$. The subjects with evidence of toxicity are shown to have significantly higher plasma digoxin concentrations $(3 \cdot 36 S D \pm I \cdot 20 \mathrm{ng} / \mathrm{ml})$ though there is some overlap with the non-toxic group. The subjects with toxicity are shown to be substantially older and to have a much higher incidence of raised blood urea. The implications of these observations are discussed.

Recent advances in knowledge of the chemistry (Henderson, 1969) and pharmacology (Dimond, 1957; Fisch and Surawicz, 1969) of the cardiac glycosides have been considerable. These advances in association with a number of careful clinical studies (reviewed by Surawicz and Mortelmans, 1969 and by Chung, 1969) have provided a more rational basis for therapy with digitalis, and have led to a much wider appreciation of the protean manifestations of digitalis intoxication and of factors that alter individual tolerance to digitalis. Paradoxically, however, the incidence of digitalis intoxication is reported to have increased conspicuously in recent years and is reported to be between 7 and 22 per cent among hospital inpatients (Rodensky and Wasserman, I961, 1964; Sodeman, 1965).

The lack of specific chemical techniques sufficiently sensitive to measure the low concentrations of glycosides present in the blood has hampered studies of these compounds. Lowenstein (1965) and Lowenstein and Corrill (1966) have developed an assay for cardiac glycosides based on the inhibition of ${ }^{86} \mathrm{Rb}$ uptake. Using this technique, Grahame-Smith and Everest (1969) and Binnion et al. (1969) have indicated that plasma digoxin assay may make better control of digoxin therapy possible. A rapid, sensitive, and precise radioimmunoassay for digoxin has recently been

Received 2 September 1970.

1 Present address: Department of Medicine, Royal Victoria Infirmary, Newcastle upon Tyne.

2 This work represents part of a study to be submitted for the degree of M.D. in the University of London. developed (Smith, Butler, and Haber, 1970; Chapman and Evered, 1970), and preliminary studies using this technique have been published (Smith, Butler, and Haber, 1969; Evered, Chapman, and Hayter, 1970). These early reports were selective in their choice of subjects and only relatively small numbers of patients have been studied.

The present systematic study was undertaken to survey the range of plasma digoxin concentrations in hospital inpatients on routine oral maintenance therapy, to assess the incidence of toxic manifestations in these subjects, and to relate these to plasma digoxin concentrations and other factors which either delay the excretion of digoxin or alter individual tolerance to the drug.

\section{Subjects and methods}

Studies were made on 108 patients on routine oral maintenance therapy with digoxin, who were admitted consecutively under the care of six physicians. The age, weight, and sex of each subject were recorded. An early morning venous blood sample was obtained from each subject before administration of the morning dose. Plasma digoxin concentration was measured in duplicate on each subject by a radioimmunoassay technique (Chapman and Evered, 1970). Plasma urea and electrolyte levels were measured by autoanalyser on the same sample. An electrocardiogram was recorded on each subject on the day the sample for assay was obtained.

All the subjects were examined for clinical or electrocardiographic evidence of digoxin intoxication. The occurrence of one or more of the following criteria was used to support a diagnosis of digoxin intoxication. 
TABLE I Summary of data obtained from 108 subjects on routine oral maintenance therapy with digoxin

\begin{tabular}{|c|c|c|c|c|c|c|c|c|c|}
\hline & No. & $\begin{array}{l}\text { Plasma } \\
\text { digoxin } \\
\text { concentra- } \\
\text { tion } \\
(\mathrm{ng} / \mathrm{ml})\end{array}$ & $\begin{array}{l}\text { Age } \\
\text { (yr) }\end{array}$ & $\begin{array}{l}\text { Age in } \\
\text { subjects } \\
\text { with urea } \\
<40 \mathrm{mg} / \\
100 / \mathrm{ml}\end{array}$ & $\begin{array}{l}\text { Blood } \\
\text { urea } \\
(m g / r o o \\
m l)\end{array}$ & $\begin{array}{l}\% \text { Subjects } \\
\text { over } 55 \\
\text { with urea } \\
>40 \mathrm{mg} / \\
\text { I00 } \mathrm{ml}\end{array}$ & $\begin{array}{l}\text { Mean } \\
\text { total } \\
\text { daily } \\
\text { dose } \\
(m g)\end{array}$ & $\begin{array}{l}\text { Plasma } \\
\text { potassium } \\
(m E q / l .)\end{array}$ & $\begin{array}{l}\text { Body } \\
\text { weight } \\
(\mathrm{kg})\end{array}$ \\
\hline Toxic subjects & $\begin{array}{l}22 \\
(20 \cdot 4 \%) \\
M: 9, F: 13\end{array}$ & $\begin{array}{l}3 \cdot 36 \\
\pm I \cdot 20\end{array}$ & $\begin{array}{l}69.9 \\
\pm 8.4\end{array}$ & $\begin{array}{l}68 \cdot 2 \\
\pm 8 \cdot 0\end{array}$ & $\begin{array}{l}57 \cdot 4 \\
\pm 37 \cdot 3\end{array}$ & $72 \cdot 7$ & $\begin{array}{l}0.53 \\
\pm 0.12\end{array}$ & $\begin{array}{l}4 \cdot 16 \\
\pm 0.39\end{array}$ & $\begin{array}{l}59.6 \\
\pm 14.9\end{array}$ \\
\hline \multirow[t]{3}{*}{ Non-toxic subjects } & $\begin{array}{l}86 \\
(79 \cdot 6 \%) \\
M: 45, F: 4 I\end{array}$ & $\begin{array}{l}1 \cdot 38 \\
\pm 0 \cdot 77\end{array}$ & $\begin{array}{l}59 \cdot 2 \\
\pm I I \cdot 6\end{array}$ & $\begin{array}{l}58 \cdot 3 \\
\pm 10 \cdot 3\end{array}$ & $\begin{array}{l}44 \cdot 9 \\
\pm 3 I \cdot 4\end{array}$ & $38 \cdot 0$ & $\begin{array}{l}0.44 \\
\pm 0.17\end{array}$ & $\begin{array}{l}4.00 \\
\pm 0.51\end{array}$ & $\begin{array}{l}65.9 \\
\pm 12.7\end{array}$ \\
\hline & & $\begin{array}{l}t=7.07 \\
P<0.001\end{array}$ & $\begin{array}{l}t=3.78 \\
P<0.00 I\end{array}$ & $\begin{array}{l}t=2.17 \\
0.05>P\end{array}$ & $\begin{aligned} 0.10 & >\mathrm{P} \\
& >0.05\end{aligned}$ & $\begin{array}{l}\chi^{2}=6.05 \\
0.025>\mathrm{P}\end{array}$ & $\begin{array}{l}t=2.39 \\
0.02>P\end{array}$ & - & - \\
\hline & & & & $>0.025$ & & $>0.310$ & $>0.01$ & & \\
\hline All subjects & $\begin{array}{l}\text { I08 } \\
M: 54, F: 54\end{array}$ & $\begin{array}{l}I \cdot 79 \\
\pm I \cdot I 8\end{array}$ & $\begin{array}{l}6 I \cdot 5 \\
\pm I I \cdot 8\end{array}$ & $\begin{array}{l}59.5 \\
\pm 10.5\end{array}$ & $\begin{array}{l}47 \cdot 7 \\
\pm 33 \cdot 0\end{array}$ & $46 \cdot 2$ & $\begin{array}{l}0.46 \\
\pm 0.16\end{array}$ & $\begin{array}{l}4.04 \\
\pm 0.49\end{array}$ & $\begin{array}{l}64.2 \\
\pm 13.5\end{array}$ \\
\hline
\end{tabular}

I) Nausea and/or vomiting - without evident other cause which resolved on withdrawal of digoxin.

2) Arrhythmias, as listed, which were not present before the onset of digoxin therapy and which resolved on withholding the drug: (a) paroxysmal supraventricular tachycardia with or without AV block; (b) wandering atrial pacemaker; (c) atrial premature contractions; (d) nodal arrhythmias; (e) heart block of any degree; and (f) ventricular premature contractions.

\section{Results}

Of the 108 subjects studied, 54 were men and 54 were women; $22(20.4 \%)$ were found to have clinical or electrocardiographic evidence of digoxin toxicity. The results are summarized in Table $\mathbf{I}$.

Subjects without evidence of digoxin toxicity The mean plasma digoxin concentration was found to be $\mathrm{I} \cdot 38 \mathrm{SD} \pm 0 \cdot 77 \mathrm{ng} / \mathrm{ml}$ in this group, on a mean daily dose of 0.44 $\mathrm{SD} \pm 0.17 \mathrm{mg} /$ day. The daily maintenance dose in the subjects observed ranged from $0.25 \mathrm{mg}$ on alternate days to $0.75 \mathrm{mg}$ daily. The mean plasma digoxin concentration and

TABLE 2 Plasma digoxin concentrations in 86 subjects without toxicity - mean values and standard deviation at each dose level

\begin{tabular}{lcll}
\hline $\begin{array}{l}\text { Total daily } \\
\text { dose }(\mathrm{mg})\end{array}$ & $\begin{array}{l}\text { No. of } \\
\text { subjects }\end{array}$ & $\begin{array}{l}\text { Mean plasma } \\
\text { digoxin } \\
\text { concentration } \\
(n g / m l)\end{array}$ & $S D$ \\
\hline 0.25 A.D. & 3 & 0.90 & - \\
0.25 & 29 & $1 \cdot 20$ & 0.84 \\
0.5 & 43 & 1.42 & 0.68 \\
0.75 & II & 1.85 & 0.86 \\
\hline
\end{tabular}

A.D. = alternate days. standard deviation at each dose level are shown in Table 2 and Fig. I. There is a significant positive correlation between total daily dose and plasma digoxin concentration $(r=0.312 ; S E=0.108)$ though there is a considerable range at each dose level.

Of the subjects in this group, 45 were men and $4 \mathrm{I}$ were women. The mean age of this group was $59 \cdot 2 \mathrm{SD} \pm \mathrm{II} \cdot 6$ years and the mean weight $65.9 \pm 12.7 \mathrm{~kg}$. The blood urea was found to be raised (greater than $40 \mathrm{mg} / 100$ $\mathrm{ml}$ ) in 38 per cent of the subjects without digoxin toxicity and the mean blood urea for the whole group was $44.9 \mathrm{SD} \pm 31 \cdot 4 \mathrm{mg} / 100$ $\mathrm{ml}$ - the variance and standard deviation are large since the group is distorted by two subjects with blood urea values of 180 and 222 $\mathrm{mg} / \mathrm{ro0} \mathrm{ml}$. The mean plasma potassium concentration was $4.00 \mathrm{SD} \pm 0.51 \mathrm{mEq} / \mathrm{l}$.

FIG. I Plasma digoxin concentrations in 86 subjects without digoxin intoxication. (Mean values represented by horizontal bars.)

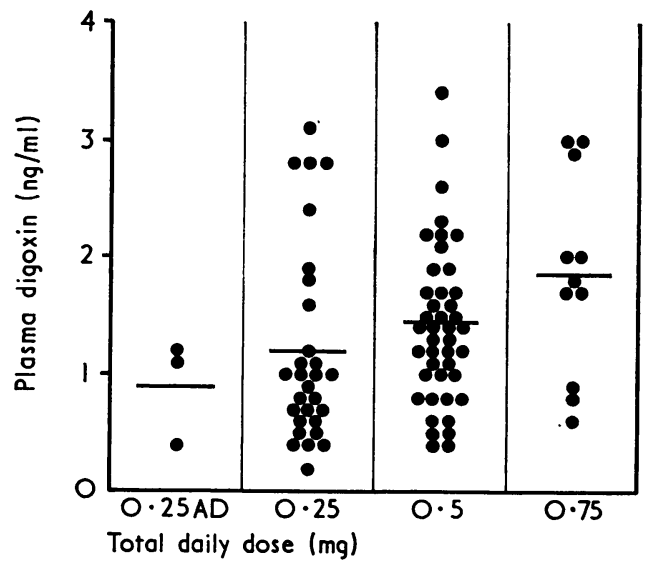


TABLE 3 Nature of digoxin toxicity in 22 subjects

\begin{tabular}{ll}
\hline Digoxin toxicity & No. of subjects \\
\hline Ventricular premature contractions & 8 \\
Nausea, anorexia, and vomiting & 7 \\
First degree heart block & 7 \\
Second degree heart block & I \\
Nodal ectopic beats & I \\
Paroxysmal atrial tachycardia with & I \\
$\quad$ block & \\
\hline
\end{tabular}

Subjects with signs of digoxin toxicity 22 subjects had evidence of digoxin toxicity. The nature of the toxic manifestations in this group is shown in Table 3. The mean plasma digoxin concentration in the subjects with digoxin toxicity was found to be 3.36 $\mathrm{SD} \pm \mathrm{r} \cdot 20 \mathrm{ng} / \mathrm{ml}$. Fig. 2 reveals that there is some overlap between the toxic and non-toxic groups mainly in the range of concentrations between 2.0 and $3.0 \mathrm{ng} / \mathrm{ml}$. The difference in plasma digoxin concentrations between the two groups is, however, highly significant $(t=7.07 ; P<0.001)$. The mean total daily dose in the subjects with toxicity was 0.53 $S D \pm 0.12 \mathrm{mg}$ compared with $0.44 \pm 0.17 \mathrm{mg}$ in the group without evidence of toxicity. This difference is also significant $(t=2.30$; $0.02>\mathrm{P}>0.01$ ).

The age of the subjects with digoxin intoxication was found to be strikingly higher than in the non-intoxicated group. Only one

FIG. 2 Plasma digoxin concentrations in subjects with and without toxicity. (Mean values represented by horizontal bars.)

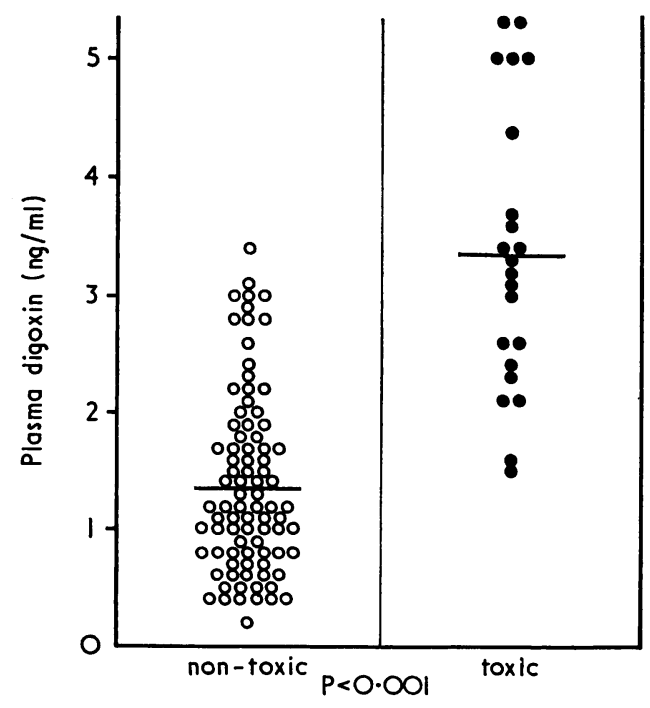

subject with digoxin toxicity among the subjects studied was less than 60 years of age. The mean age of the toxic group was found to be $69.9 \mathrm{SD} \pm 8.4$ years and this is significantly higher than in the non-toxic group $(t=3.78 ; P<0.001)$. It is also noteworthy that the blood urea is higher in the toxic group mean $57.4 \mathrm{SD} \pm 37.3 \mathrm{mg} / \mathrm{ro0} \mathrm{ml}$. Of 22 $(72 \cdot 7 \%)$ in this group, 16 had a high blood urea $(41 \mathrm{mg} / 100 \mathrm{ml}$ or greater) and the incidence of a high blood urea is significantly greater in this group than in the non-toxic group $\left(\chi^{2}=6.80,0.01>P>0.005\right.$. $)$ Further analysis reveals that these differences in age and blood urea are not interdependent. The mean age of the subjects with digoxin toxicity and a normal blood urea is $68.2 \mathrm{SD} \pm 8.0$ years, and this is significantly higher than the mean age of the non-toxic subjects with a normal blood urea $(t=2.17,0.05>P>0.025)$. Conversely the incidence of high blood urea is much higher in the toxic group (72.7\%) than in the non-toxic group (38\%) in subjects over the age of 55, and this difference is significant $\left(\chi^{2}=6.050,0.025>P>0.010\right)$.

It was found that there was no significant difference in the sex ratio between the toxic and non-toxic groups. The plasma potassium concentration in each group was similar. The mean weight of the toxic group $(59.6 \mathrm{~kg})$ was a little lower than that of the non-toxic group but the difference was not significant. Further comparison of the toxic group with the subjects in the non-toxic group aged over 55 years again reveals no significant difference between the body weight of the two groups.

The toxic group was further studied and compared with those subjects in the nontoxic group who had plasma digoxin concentrations in excess of $2.0 \mathrm{ng} / \mathrm{ml}$ (Table 4). This comparison confirms that the mean age of the toxic group is again much higher than that of the non-toxic group $(t=3 \cdot 10,0.005>$ $P>0.001$ ). There was, however, no significant difference in the incidence of a raised blood urea between the toxic group and the nontoxic subjects with a plasma digoxin concentration greater than $2 \cdot 0 \mathrm{ng} / \mathrm{ml}$. Once again there was no significant difference between the sex ratio, body weight, or plasma potassium concentration between the two groups.

It is of interest to note that 13 of a total of 22 subjects with digoxin toxicity had ischaemic heart disease, while only 7 out of 18 nontoxic subjects with plasma digoxin concentrations greater than $2.0 \mathrm{ng} / \mathrm{ml}$ had ischaemic heart disease. The comparable figures for rheumatic heart disease in the two groups are 2 subjects and 7 subjects. These differences are not statistically significant but they may 
TABLE 4 Summary of data obtained from subjects with digoxin toxicity and subjects without toxicity with plasma digoxin concentrations greater than $2 \cdot 0 \mathrm{ng} / \mathrm{ml}$

\begin{tabular}{|c|c|c|c|c|c|c|}
\hline & No. of subjects & $\operatorname{Age}(y r)$ & $\begin{array}{l}\text { Blood urea } \\
(\mathrm{mg} / \mathrm{I} 00 \mathrm{ml})\end{array}$ & $\begin{array}{l}\text { Subjects with } \\
\text { urea }>40 \mathrm{mg} / \\
100 \mathrm{ml}\end{array}$ & $\begin{array}{l}\text { Plasma } \\
\text { potassium } \\
(m E q / l .)\end{array}$ & $\begin{array}{l}\text { Weight } \\
(\mathrm{kg})\end{array}$ \\
\hline & $\begin{array}{l}22 \\
M: 9, F: 13\end{array}$ & \multirow{3}{*}{$\begin{array}{l}69.9 \\
\pm 8.4 \\
56 \cdot 1 \\
\pm 15.6 \\
t=3 \cdot 10 \\
0.005>P>0.001\end{array}$} & $\begin{array}{l}57 \cdot 4 \\
+37 \cdot 3\end{array}$ & $72 \cdot 7$ & $\begin{array}{l}4.16 \\
+0.39\end{array}$ & $\begin{array}{l}59 \cdot 6 \\
+14.9\end{array}$ \\
\hline Non-toxic subjects & $\mathrm{M}: 7, \mathrm{~F}: \mathrm{I2}$ & & $\begin{array}{l}5 I \cdot I \\
\pm 38 \cdot 9\end{array}$ & $47 \cdot 1$ & $\begin{array}{l}4.27 \\
\pm 0.44\end{array}$ & $\begin{array}{l}60 \cdot 0 \\
\pm 14 \cdot 1\end{array}$ \\
\hline & & & - & $0.20>\mathrm{P}>0.10$ & - & - \\
\hline
\end{tabular}

be of clinical importance. It is also noteworthy that the 3 subjects among the I08 studied who were hypothyroid all had evidence of digoxin toxicity, and in these 3 subjects the toxicity occurred at low plasma digoxin concentrations $(\mathrm{r} \cdot 5, \mathrm{r} \cdot 6$, and $2 \cdot \mathrm{Ig} / \mathrm{ml})$.

\section{Discussion}

Earlier studies of plasma digoxin concentrations using the radioimmunoassay technique (Smith et al., 1969) or the inhibition of ${ }^{86} \mathrm{Rb}$ uptake method (Lowenstein and Corrill, 1966; Grahame-Smith and Everest, 1969; Binnion et al., 1969) have been selective in their choice of subjects for study - in particular in their exclusion of subjects with early or minor signs of digoxin intoxication. It is likely that the values for plasma digoxin concentration reported here are representative of a hospital inpatient population.

The mean plasma digoxin concentrations measured in the 86 subjects without evidence of digoxin toxicity are very similar to those reported by Smith et al. (1969). A wider range of values however has been observed than in the 2 I subjects reported by Smith et al. (1969) - which is in part accounted for by the wider range of dose levels observed in the present group. These values agree well with those reported for normal subjects by Marcus et al. (1966) after the administration of ${ }^{3} \mathrm{H}-$ digoxin. It is noteworthy that both the mean value for plasma digoxin concentration and the standard deviation $(\mathrm{r} \cdot 38 \pm 0 \cdot 77 \mathrm{ng} / \mathrm{ml})$ are substantially lower than those previously reported $(\mathrm{I} \cdot 63 \pm \mathrm{I} \cdot 13 \mathrm{ng} / \mathrm{ml})$ in subjects in whom the measurements were not time-related to the administration of the dose (Evered et al., 1970). It should be emphasized that such measurements are of limited value. Nevertheless, a wide range of plasma digoxin concentrations appears to be consistent with effective therapy. These findings are in keeping with the wide range of myocardial:serum digoxin concentrations which have been reported by other workers (Doherty, Perkins, and Flanigan, 1967; Binnion et al., 1969).

The incidence of digoxin toxicity in the hospital inpatients studied here was 20 per cent and this value falls within the range of incidences $(7-22 \%)$ reported by other workers (Rodensky and Wasserman, 1961, I964; Sodeman, 1965). The plasma digoxin concentration is significantly higher in the toxic subjects studied - though it is clear that there is a range of plasma digoxin concentrations (largely between 2.0 and $3.2 \mathrm{ng} / \mathrm{ml}$ ) where intoxication may or may not occur. This overlap of the toxic and non-toxic ranges is not unexpected in view of the wide range of myocardial:serum digoxin ratios which have been reported - and, also, as Surawicz and Mortelmans (1969) and Chung (1969) have pointed out in recent reviews, there are numerous factors that appear to alter individual tolerance to cardiac glycosides. The most striking difference between the toxic and non-toxic subjects studied here is in respect of the age of the two groups. It has been shown that the age of the toxic group is considerably higher than that of the non-toxic subjects. The effect of age is shown to be independent of diminished renal function. The difference in age between the toxic subjects and non-toxic subjects with a plasma digoxin concentration greater than $2 \cdot 0 \mathrm{ng} / \mathrm{ml}$ is also significant, and suggests that tolerance to cardiac glycosides is reduced with age. This diminished tolerance to digitalis in the older subjects may be related to the increased incidence of myocardial disease in the ageing population - though earlier clinical studies have suggested that these two factors are not interdependent (Kay, 1955; Shrager, 1957; Soffer, 1961 ; Dreifus et al., 1963; Dall, 1965). The incidence of ischaemic heart disease is higher than that of rheumatic heart disease in the subjects with toxicity while the reverse is true of the subjects without toxicity, but a high plasma digoxin concentration. More extensive studies are required to determine whether these differences merely represent 
the different incidences of rheumatic and ischaemic heart disease in the two age groups or whether the increased incidence of myocardial ischaemia is responsible for diminished tolerance to cardiac glycosides in the aged.

A significantly greater proportion of the toxic subjects had a raised blood urea than the non-toxic group - and the increased incidence of toxicity in this group appears to be directly related to the raised plasma digoxin concentrations in these subjects. Digoxin which is a relatively polar glycoside is largely excreted by the kidney unchanged (Marcus, Kapadia, and Kapadia, 1964), and thus this association between raised blood urea and raised plasma concentrations of digoxin associated with toxicity is not unexpected and emphasizes that caution is necessary when administering digoxin to subjects with impaired renal function.

It is noteworthy that the plasma potassium concentrations in the toxic subjects studied were similar to those in the non-toxic subjects. The relation between hypokalaemia and digitalis-induced arrhythmias (particularly ventricular arrhythmias) has been emphasized by many workers (Lown et al., I952; Chung and Thomas, I965; Davidson and Surawicz, 1967), and the risk of diuretics inducing hypokalaemia has been emphasized. Those subjects studied who were being treated with diuretics were also receiving potassium supplements, and it was striking that the lowest plasma potassium concentration in the subjects with toxicity was $3.7 \mathrm{mEq} / \mathrm{l}$. It appears that the emphasis which this problem has been given has borne fruit.

There was no significant difference in sex incidence between the toxic and non-toxic subjects observed. This finding is at variance with that of Rodensky and Wasserman (1964) who found a considerably higher incidence of digitalis-induced arrhythmias in male than female patients. However, the patients studied by these workers were all under the age of 40 , and it may be that the incidence of toxicity in older patients is equal.

The observations reported here that the three subjects with digoxin toxicity who were hypothyroid had the three lowest 'toxic' plasma digoxin concentrations recorded is of interest. Thyroid hormone modifies the metabolism of digitalis (Braunwald and Klocke, 1965) and after the administration of ${ }^{3} \mathrm{H}$-digoxin the drug is cleared more slowly from the plasma in hypothyroid than in normal subjects (Doherty and Perkins, 1966). These findings are consistent with the clinical observation that digoxin toxicity may develop when thyrotoxicosis is treated if the dose of digoxin is not reduced (Somlyo, 1960). However, the occurrence of toxicity at relatively low plasma digoxin concentrations leads one to speculate that myocardial sensitivity to cardiac glycosides may also be increased in hypothyroidism.

The systematic study of hospital inpatients shows the range of plasma digoxin concentrations that are seen in subjects on routine oral maintenance therapy and emphasizes the value of the measurement of plasma digoxin concentration in the control of digoxin therapy. It is also clear, however, that the relation between plasma digoxin concentration and recognized digitalis toxicity (which is based on clinical and electrocardiographic criteria) is not a simple one.

We are grateful to Dr. C. J. Hayter for his advice and encouragement throughout this work - and also to those physicians who co-operated by allowing us to study their patients.

\section{References}

Binnion, P. F., Morgan, L. M., Stevenson, H. M., and Fletcher, E. (1969). Plasma and myocardial digoxin concentrations in patients on oral therapy. British Heart fournal, 31, 636.

Braunwald, E., and Klocke, F. J. (1965). Digitalis. Annual Review of Medicine, 16, 371.

Chapman, C., and Evered, D. C. (1970). The development of a radioimmunoassay for digoxin and characteristics of digoxin-specific antibodies. In preparation.

Chung, E. K. (1969). Digitalis Intoxication. Excerpta Medica Foundation, Amsterdam.

Chung, E. K., and Thomas, J. (1965). Arrhythmias caused by digitalis toxicity. Geriatrics, $20,1006$.

Dall, J. L. C. (1965). Digitalis intoxication in elderly patients. Lancet, I, I94.

Davidson, S., and Surawicz, B. (1967). Ectopic beats and atrioventricular conduction disturbances in patients with hypopotassemia. Archives of Internal Medicine, 120, 280.

Dimond, E. G. (1957). (Ed.) Digitalis. Charles C. Thomas, Springfield, Illinois.

Doherty, J. E., and Perkins, W. H. (1966). Digoxin metabolism in hypo- and hyperthyroidism. Annals of Internal Medicine, 64, 489.

Doherty, J. E., Perkins, W. H., and Flanigan, W. J. (1967). The distribution and concentration of tritiated digoxin in human tissues. Annals of Internal Medicine, 66, 116.

Dreifus, L. S., McKnight, E. H., Katz, M., and Likoff, W. (1963). Digitalis intolerance. Geriatrics, 18, 494.

Evered, D. C., Chapman, C., and Hayter, C. J. (1970). Measurement of plasma digoxin concentration by radioimmunoassay. British Medical Fournal, 3, 427.

Fisch, C., and Surawicz, B. (1969). (Eds.) Digitalis. Grune and Stratton, New York.

Grahame-Smith, D. G., and Everest, M. S. (1969). Measurement of digoxin in plasma and its use in diagnosis of digoxin intoxication. British Medical fournal, r, 286.

Henderson, F. G. (1969). Chemistry and biological activity of the cardiac glycosides. In Digitalis, p. 3 . Ed. by C. Fisch and B. Surawicz. Grune and Stratton, New York. 
Kay, C. F. (1955). The clinical use of digitalis preparations. Circulation, 12, 116 and 291.

Lowenstein, J. M. (I965). A method for measuring plasma levels of digitalis glycosides. Circulation, 31, 228.

Lowenstein, J. M., and Corrill, E. M. (1966). An improved method for measuring plasma and tissue concentrations of digitalis glycosides. Fournal of Laboratory and Clinical Medicine, 67, 1048.

Lown, B., Weller, J. M., Wyatt, N., Hoigne, R., and Merrill, J. P. (I952). Effects of alteration of body potassium on digitalis toxicity. Fournal of Clinical Investigation, 31, 648.

Marcus, F. I., Burkhalter, L., Cuccia, C., Pavlovich, J., and Kapadia, G. G. (1966). Administration of tritiated digoxin with and without a loading dose. A metabolic study. Circulation, 34, 865.

Marcus, F. I., Kapadia, G. J., and Kapadia, G. G. (1964). The metabolism of digoxin in normal subjects. Fournal of Pharmacology and Experimental Therapeutics, 145, 203.

Rodensky, P. L., and Wasserman, F. (1961). Observations on digitalis intoxication. Archives of Internal Medicin?, 108, 17 r.
Rodensky, P. L., and Wasserman, F. (1964). The possible role of sex in digitalis tolerance. American Heart fournal, 68, 325.

Shrager, M. W. (1957). Digitalis intoxication. American Heart fournal, 100, 881.

Smith, T. W., Butler, V. P., and Haber, E. (1969). Determination of therapeutic and toxic serum digoxin concentrations by radioimmunoassay. New England fournal of Medicine, 281, 1212.

Smith, T. W., Butler, V. P., and Haber, E. (1970) Characterization of antibodies of high affinity and specificity for the digitalis glycoside digoxin. Biochemistry, 9, 33I.

Sodeman, W. A. (1965). Diagnosis and treatment of digitalis toxicity. New England fournal of Medicine, 273, 35 .

Soffer, A. (196r). The changing clinical picture of digitalis intoxication. Archives of Internal Medicine, r07, 681.

Somlyo, A. P. (1960). The toxicology of digitalis. American fournal of Cardiology, 5, 523.

Surawicz, B., and Mortelmans, S. (I969). Factors affecting individual tolerance to digitalis. In Digitalis, p. 127. Ed. by C. Fisch and B. Surawicz. Grune and Stratton, New York. 